IZA DP No. 5511

Does Anti-Competitive Regulation Matter for Productivity? Evidence from European Firms

Jens Matthias Arnold

Giuseppe Nicoletti

Stefano Scarpetta

February 2011 


\title{
Does Anti-Competitive Regulation Matter for Productivity? Evidence from European Firms
}

\author{
Jens Matthias Arnold \\ OECD \\ Giuseppe Nicoletti \\ OECD \\ Stefano Scarpetta \\ $O E C D$ and IZA
}
Discussion Paper No. 5511
February 2011

\author{
IZA \\ P.O. Box 7240 \\ 53072 Bonn \\ Germany \\ Phone: +49-228-3894-0 \\ Fax: +49-228-3894-180 \\ E-mail: iza@iza.org
}

\begin{abstract}
Any opinions expressed here are those of the author(s) and not those of IZA. Research published in this series may include views on policy, but the institute itself takes no institutional policy positions.

The Institute for the Study of Labor (IZA) in Bonn is a local and virtual international research center and a place of communication between science, politics and business. IZA is an independent nonprofit organization supported by Deutsche Post Foundation. The center is associated with the University of Bonn and offers a stimulating research environment through its international network, workshops and conferences, data service, project support, research visits and doctoral program. IZA engages in (i) original and internationally competitive research in all fields of labor economics, (ii) development of policy concepts, and (iii) dissemination of research results and concepts to the interested public.
\end{abstract}

IZA Discussion Papers often represent preliminary work and are circulated to encourage discussion. Citation of such a paper should account for its provisional character. A revised version may be available directly from the author. 
IZA Discussion Paper No. 5511

February 2011

\section{ABSTRACT \\ Does Anti-Competitive Regulation Matter for Productivity? Evidence from European Firms ${ }^{*}$}

Using firm-level data for a sample of European countries, we focus on the effects that product-market regulations have on firm-level TFP growth. We proxy regulatory burdens using the OECD indicators of sectoral non-manufacturing regulations. These allow accounting for both the direct effects of sectoral regulation on within-sector performance and the indirect effects of sectoral regulation on firms in other sectors through intersectoral inputoutput linkages. Our econometric specification of TFP is based on a "neo-Schumpeterian" empirical specification in which productivity improvements depend on growth at the global technological frontier and a catch up term. We assume that regulation can affect productivity growth both directly and by slowing down the rate of catch up. We find that product market regulations that curb competitive pressures tend to reduce the productivity performance of firms. The negative effect is particularly strong on firms characterised by an above-average productivity growth. Domestic regulations that affect all regulated firms in the same way seem to be more important than border regulations in this context.

JEL Classification: D24, L11, L51

Keywords: $\quad$ total factor productivity, firm-level data, product market regulation

Corresponding author:

Stefano Scarpetta

OECD

Directorate for Employment, Labour and Social Affairs

2, Rue André Pascal

75775 Paris Cedex 16

France

E-mail: stefano.scarpetta@oecd.org

\footnotetext{
* The authors wish to thank conference and seminar participants at the European Central Bank, CESifo Institute, the Bank of Italy, the University of Rome "La Sapienza", the University of Milan "Cattolica" and Imperial College, London for their useful comments on a previous version of this paper. The views expressed in this paper are those of the authors and should not be taken to represent those of the OECD Secretariat or its member countries.
} 


\section{Introduction}

In almost all industrialised economies, governments intervene in product markets through regulatory policies, particularly in services industries. Regulation in product markets is generally motivated by market failures, including monopoly conditions, externalities and asymmetric information. However, if poorly designed, product market regulations may also affect the degree of competition between firms by raising barriers to entry, placing restrictions on product choices or firm operations, or granting protection to incumbent special interest groups. Such anti-competitive effects of regulations can, in turn, limit firms' incentives to maximise efficiency and innovate. While some countries have managed to address public interest concerns in non-manufacturing sectors without much harm to competitive forces, other countries -particularly in continental Europe- have reduced the dynamism of some of these industries through excessively strict regulation. In this paper we relate anti-competitive regulatory policies and firm-level productivity growth in downstream sectors in 10 European countries, focusing on ways in which illdesigned regulations can harm productivity and not on the potential benefits of appropriate regulations.

\section{Measuring regulation, inter-industry linkages and firm productivity}

\section{Indicators of product market regulations}

Our measure of regulation is a comprehensive set of policy indicators assembled at the OECD on the basis of extensive surveys of national regulatory practices in services industries across sectors, countries and time. These industry-specific product market regulation (PMR) indicators cover two broad groups of services sectors: network industries, including energy (electricity and gas), transport (air, rail and road transport) and communication (post and telecommunications); and retail trade and professional services. They quantify anti-competitive restrictions in regulatory domains such as State control, barriers to entry, involvement in business operations, and, in some cases, vertical integration and market structure. ${ }^{2}$

The effects of policy-induced rigidities in non-manufacturing industries are not limited to these sectors themselves, but can also generate trickle-down effects into other sectors by raising the costs or lowering the quality of intermediate inputs, particularly in the case of services inputs where import competition is limited. ${ }^{3}$ Hence we pre-multiply the sector-specific regulation indicators for services industries by a matrix of input-output coefficients for 39 sectors, on the basis of the 2000 input-output tables for the United States. Using data from the United States -which are not part of our estimation sample- avoids the possible endogeneity of national input-output coefficients to national market characteristics such as the degree of competition. ${ }^{4}$ This results in an indicator matrix that we call regulation impact indicators, calculated as:

2 See Conway and Nicoletti (2006) and Woelfl et. al. (2009) for a complete description of the OECD PMR indicators, which are also available on line at www.oecd.org/eco/pmr .

3 Bourles et al. (2010) present a theoretical model of how productivity may be affected by the degree of competition in upstream sectors.

This strategy is similar to Rajan and Zingales (1998), who use measures of financial dependence of US industries in a cross-country regression setting. The underlying assumption is that the US has a comparatively strong degree of competition in most non-manufacturing sectors and thus US coefficients may be adequate proxies of intersectoral input-output relations in the absence of competition-reducing policy distortions. Moreover, the data quality of the US Input-Output matrix seems to be superior to those of a number of other countries in our sample. 


$$
R I_{j c t}=\sum_{j^{\prime}} w_{j j^{\prime}} \cdot P M R_{j^{\prime} c t}
$$

where subscripts $c$ denote countries, $j$ and $j^{\prime}$ industries (where $j^{\prime}$ is defined for the above-mentioned regulated services industries only) and t time. $\mathrm{w}_{\mathrm{jj}}$, are input-output coefficients measuring the intensity with which industry $\mathrm{j}$ relies on services industry $\mathrm{j}$ '. Our identifying assumption is that sectors that are more dependent on a given kind of services inputs should be more affected by a lack of competition in this upstream sector. The so-constructed regulation impact indicators RI cover 39 sectors that use the outputs of services industries as intermediate inputs. Note that for services sectors, the cross-diagonal elements of the input-output matrix are often large.

\section{The firm-level database}

We relate these regulation impact indicators to firms' productivity, using firm-level data drawn from the Amadeus database of the Bureau van Dijk. Our firm-level sample includes ten European countries for which the Amadeus database has a good coverage of firms, ${ }^{5}$ over the years 1998 to 2004. As any firmlevel data set, the raw Amadeus data contain missing values for some variables that are required for the productivity estimates. This implies that once TFP estimates are obtained, we are in fact left with a different sample from the original one. In order to ensure representativeness of our effective firm-level sample along the three dimensions country, sector and size groups, we resample the original Amadeus data set. In a first step, we obtain information about the true underlying population of firms above 20 employees along these three dimensions from the Eurostat Structural Business Statistics database for the year 2000. The size group below 20 employees had to be discarded due to an unsatisfactory coverage in the Amadeus data. Then we set the total sample size to 100,000 firms (not observations) and divide this number into size-sector-country strata according to the true population. As a final step, random draws with replacement from each size-sector-country strata in the TFP sample are taken until the weight of each strata corresponded to its population weight. The results of this resampling procedure are shown in Figure 1, where Panel A compares the size distributions of our estimation sample with the true population, while Panel B does the same for the industry distribution. In both cases, our re-sampled firmlevel data set comes very close to the true population. 


\section{Figure 1. Firm population vs. Estimation Sample after resampling}

Panel A: Size distribution

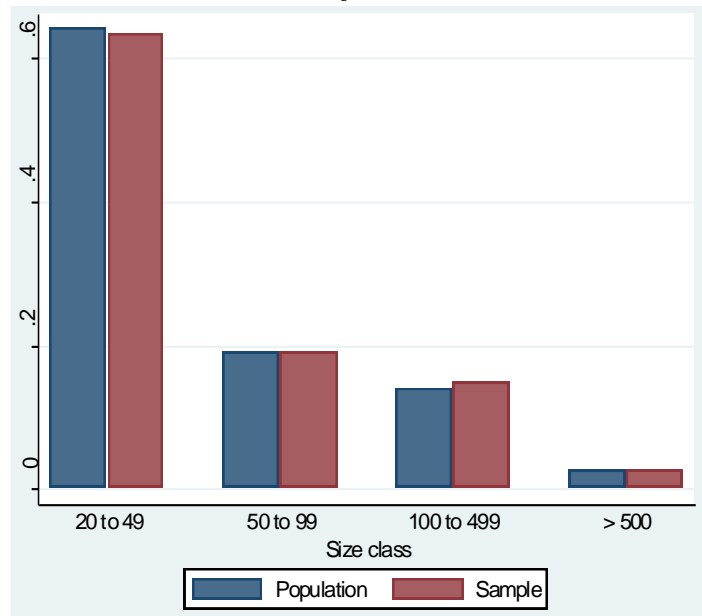

Panel B: Industry distribution

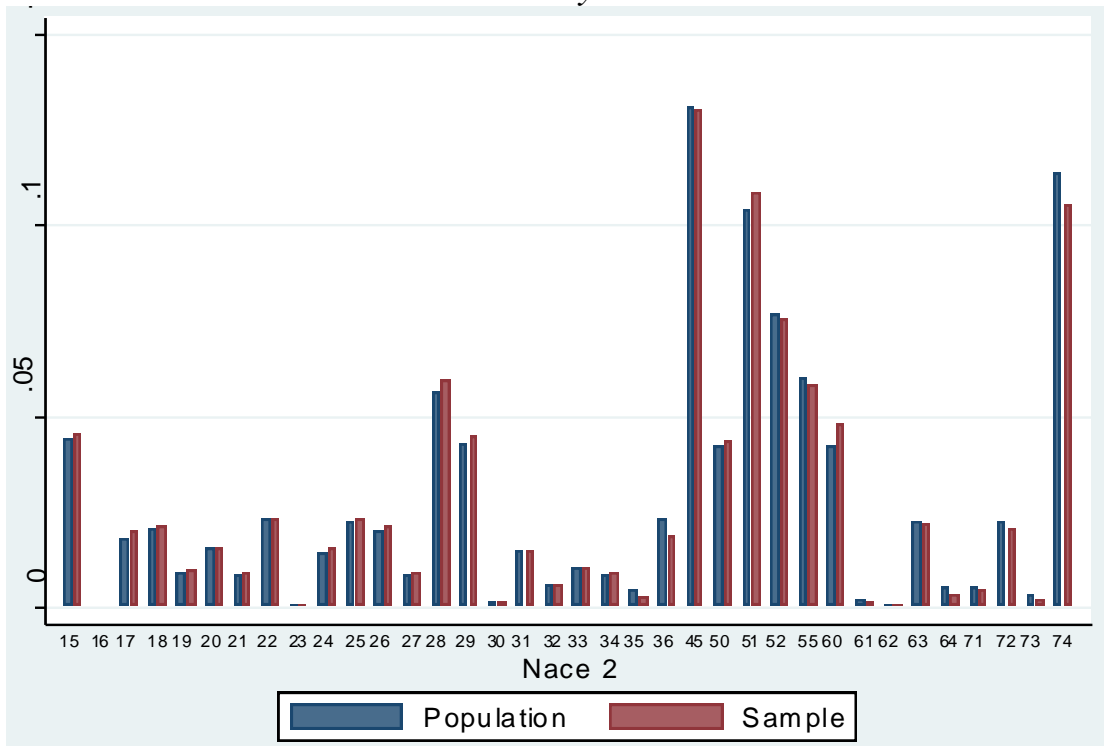

\section{TFP estimates}

TFP estimates are obtained using a superlative index number approach (see Caves et al. 1982a,b, and Griffith et al. 2009 for an application), which -unlike TFP estimates based on parametrisations of the production function- allows comparisons in levels across countries and sectors. Following Griffith et al. (2009), the superlative index measures of TFP growth and TFP level in firm $i$ at time $t$ are calculated as a function of value added $\mathrm{Y}$ and the two input factors labour and capital, denominated $\mathrm{x}^{\mathrm{z}}$ (with $\mathrm{z}=1,2$ ):

$$
\begin{aligned}
& \Delta T F P_{i t}=\Delta \ln Y_{i t}-\sum_{z=1}^{2} \tilde{\alpha}_{i t}^{z} \Delta \ln x_{i t}^{z}, \\
& T F P_{i t}=\ln \left(Y_{i t} / \bar{Y}_{j}\right)-\sum_{z=1}^{2} \sigma_{i}^{z} \ln \left(x_{i t}^{z} / \bar{x}_{j}^{z}\right)
\end{aligned}
$$

where $\tilde{\alpha}_{\text {it }}^{\mathrm{z}}$ is a two-period average of the factor compensation shares in value added $\left(\tilde{\alpha}_{\mathrm{it}}^{\mathrm{z}}=1 / 2 \alpha_{\mathrm{it}}^{\mathrm{z}}+1 / 2 \alpha_{\mathrm{it}-1}^{\mathrm{z}}\right)$. In the levels equation, upper bars depict geometric means of all firms in the same industry over all countries and years, and $\sigma_{i}^{z}=\alpha_{i}^{z}+\bar{\alpha}_{j}^{z}$ is the average of the factor share in firm $i$ and the geometric mean factor share in industry $j$. Constant returns to scale are assumed by imposing $\sum_{z} \tilde{\alpha}_{i t}^{z}=1$ and $\sum_{z} \sigma_{i}^{z}=1$. Note that as a robustness check, section 5 presents results on the basis of TFP estimates obtained through the semi-parametric estimation technique of Levinsohn and Petrin (2003). ${ }^{6}$ In both cases we use a value

Note that it is not possible to follow the methodology of Olley \& Pakes (1996). The reason is that we do not have primary information on investment in Amadeus so that investment has to be calculated as the residual between current and lagged capital stock after correcting for depreciation. This clearly violates Olley \& Pakes' (1996) orthogonality condition between lagged capital stock and investment 
added specification, based on primary information for value added, correcting for extraordinary profits. In those cases where primary information on value added was not available we imputed value added as the residual between operating revenue and material inputs. For capital stocks we use primary information on net capital stocks. For labour we use primary information on the total wage bill. Nominal values are deflated using price indices from the EUKLEMS or OECD STAN databases. We do not use estimated MFP values which either the coefficient on capital stocks or the wage bill is negative. Productivity observations for which the sum of the coefficients is smaller than 0.6 are also dropped.

\section{Empirical approach}

The regression approach we use for relating firm productivity to the regulation impact indicators is based on a catch-up specification of firm-level productivity whereby, within each sector, the production possibility set is influenced by technological and organisational transfer from the technology-frontier firms (measured as the 5\% most productive firms in sector $\mathrm{s}$ and year $\mathrm{t}$ in our sample of countries) to other firms and on the distance of the firm to the technological frontier. ${ }^{7}$ This specification is consistent with recent models of endogenous growth like Acemoglu et al. (2003) or Aghion and Howitt (1998, Ch. 8 ) in which productivity growth depends on both the ability to catch up and the ability to innovate. We model firm-level TFP for a given firm i in country $c$, industry $s$ at time $t$ as an auto-regressive distributed lag ADL $(1,1)$ process in which the level of TFP is co-integrated with the level of TFP of the frontier firm F. Formally,

$$
\ln A_{i c s t}=\alpha_{0} \ln A_{i c s t-1}+\alpha_{1} \ln A_{F c s t}+\alpha_{2} \ln A_{F c s t-1}+\alpha_{3} R I_{c s t-1}+\gamma_{s}+\gamma_{c t}+\varepsilon_{i c s t}
$$

where $A_{\text {icst }}$ is the TFP level of a non-frontier firm $i, A_{F c s t}$ is the TFP level at the technological frontier $F, R I$ is the regulation impact indicator, and $\gamma_{\mathrm{s}}, \gamma_{\mathrm{ct}}$ are sector and country-year fixed effects, respectively. Finally, $\varepsilon_{\text {icst }}$ is a random error term. Under the assumption of long-run homogeneity $\left(\alpha_{0}+\alpha_{1}+\alpha_{2}=1\right)$, the $\operatorname{ADL}(1,1)$ process in equation (2) has the following Error Correction Model (ECM) representation:

$$
\Delta \ln A_{i c s t}=\alpha_{1} \Delta \ln A_{F c s t}-\left(1-\alpha_{0}\right) \ln \left(\frac{A_{i c s, t-1}}{A_{F c s, t-1}}\right)+\alpha_{3} R I_{c s t-1}+\gamma_{s}+\gamma_{c t}+\varepsilon_{i c s t}
$$

Equation 5 is the baseline specification of the policy-augmented TFP equation. The inclusion of dummy variables for each country-year combination implies that we control for all possible omitted factors that are specific to each country in each year, which substantially reduces concerns about a possible endogeneity of policies and reverse causation. The coefficient $\alpha_{3}$ is identified using only cross-industry variation within the same country and year, which is possible because of the interaction of the original PMR regulation indicators with the industry-specific Input-Output coefficients. Since the identification strategy is based on comparisons of changes across industries within countries and year, compared across different countries and years, it can be given a difference-in-difference interpretation. ${ }^{8}$ Standard errors are clustered by country and sector to allow the error term to be correlated across firms and time within sectors in the same country (Moulton, 1991, Bertrand et al. 2004).

The analysis focuses on productivity growth of incumbents across different industries and countries. Reallocation of productive inputs and outputs via the entry and exit of firms cannot be explored with the

$7 \quad$ In the robustness checks based on Levinsohn-Petrin TFP estimates, we use a national productivity frontier definition because these TFP estimates come from country-specific production function estimates. One of the advantages of the superlative index measure is that it avoids this national frontier definition. 
Amadeus data, which do not accurately distinguish between entry into the market and entry into the sample or mergers, and between exit from the market and from exit from the sample. We can look at the role of reallocation among incumbents for productivity developments, however, by singling out those firms that are characterised by a fast catch-up to the productivity frontier (those that have approached the frontier faster than the median firm in the same country and industry over the last year) and interact an indicator variable for these firms with the regulation impact indicator. This allows us to test whether these "dynamic" firms are affected differently by anti-competitive regulation.

The PMR regulation indicators also allow a further breakdown of regulations into purely domestic regulations that apply to all firms operating in the regulated services industries regardless of their national origin, and rules that affect foreign direct investors in particular. Given that foreign direct investment (FDI) is often more relevant for cross-border market entry in these sectors than arms-length exports and that tariffs were zero for trade within the European Union throughout our sample period, we interpret this breakdown as distinction between the effects of upstream domestic regulation and upstream border regulation on domestic firms, and report distinct estimates for these two aspects of services regulation.

\section{Results}

Table 1 presents estimates of the baseline specification of the productivity equation for the regulation impact indicators in column 1 and for the additional distinction between domestic and border regulations in column 2. We find that outward shifts in the technological frontier (labelled frontier growth in the table) increase the productivity of follower firms, and that productivity growth increases in the distance to the technology frontier (TFP gap in the table), reflecting some degree of conditional productivity convergence. ${ }^{9}$ Our main variable of interest, the coefficient estimate for the regulatory impact variable $\left(\alpha_{3}\right.$ in equation 5), has a statistically significant negative coefficient, consistent with the idea that more stringent product market regulation upstream reduces the productivity of firms in downstream sectors. When we further distinguish between domestic and border regulations, we find that this result is mainly driven by domestic regulations, while border regulations do not seem to have statistically significant effects.

When we add an additional distinction between more and less dynamic firms in columns 3 and 4, we obtain a larger coefficient estimate for firms with an above-average catch-up rate with the productivity frontier, and the difference is statistically significant as shown in the F-test at the bottom of the table. When we then distinguish between domestic and border regulations we find that while domestic regulations have a strong and statistically significant effect on both dynamic and non-dynamic firms, border regulations have a statistically significant effect on dynamic firms only, while the effect on nondynamic firms is still estimated with a large standard error.

9 This is a standard finding in line with previous cross-country evidence at the sectoral level (Griffith et al., 2004; Nicoletti and Scarpetta, 2003, Conway et al., 2006 and Inklaar et al, 2008) and national evidence at the firm level (Griffith et al. 2009, for the United Kingdom). 
Table 1. Regulation and TFP: the effects of firm-level heterogeneity

\begin{tabular}{|c|c|c|c|c|}
\hline \multirow{3}{*}{ Variable } & (1) & (2) & (3) & (4) \\
\hline & \multicolumn{2}{|c|}{ Baseline } & \multicolumn{2}{|c|}{ Dynamic vs non-dynamic firms $^{1}$} \\
\hline & Overall regulation & $\begin{array}{l}\text { Border vs domestic } \\
\text { regulation }\end{array}$ & Overall regulation & $\begin{array}{l}\text { Border vs domestic } \\
\text { regulation }\end{array}$ \\
\hline Frontier Growth & $\begin{array}{l}0.065^{* * *} \\
(0.008)\end{array}$ & $\begin{array}{l}0.071^{* \star \star} \\
(0.009)\end{array}$ & $\begin{array}{l}0.145^{* * *} \\
(0.010)\end{array}$ & $\begin{array}{l}0.152^{* * *} \\
(0.011)\end{array}$ \\
\hline MFP Gap, $t-1$ & $\begin{array}{l}-0.113^{\star \star *} \\
(0.009)\end{array}$ & $\begin{array}{l}-0.126^{\star \star \star} \\
(0.006)\end{array}$ & $\begin{array}{l}-0.135^{\star \star \star} \\
(0.009)\end{array}$ & $\begin{array}{l}-0.149^{\star \star \star} \\
(0.005)\end{array}$ \\
\hline Regulation, $t-1$ & $\begin{array}{l}-0.093^{* * *} \\
(0.028)\end{array}$ & & & \\
\hline Regulation, $t-1^{\star}$ Dynamic & & & $\begin{array}{l}-0.111^{\star \star \star} \\
(0.031)\end{array}$ & \\
\hline Regulation, $t-1^{*}$ Non-dynamic & & & $\begin{array}{l}-0.075^{\star \star \star} \\
(0.030)\end{array}$ & \\
\hline Dynamic firm dummy & & & $\begin{array}{l}0.1399^{\star * \star} \\
(0.005)\end{array}$ & $\begin{array}{l}0.140^{* * *} \\
(0.006)\end{array}$ \\
\hline Regulation domestic, $t-1$ & & $\begin{array}{l}-0.073^{\star \star \star} \\
(0.027)\end{array}$ & & \\
\hline Regulation border, $t-1$ & & $\begin{array}{l}-0.091 \\
(0.077)\end{array}$ & & \\
\hline Regulation dom., $t-1$ * Dynamic & & & & $\begin{array}{l}-0.077^{* * *} \\
(0.024)\end{array}$ \\
\hline Regulation dom., $t-1$ * Non-dynamic & & & & $\begin{array}{l}-0.0599^{* *} \\
(0.025)\end{array}$ \\
\hline Regulation border, $t-1$ * Dynamic & & & & $\begin{array}{l}-0.167^{* *} \\
(0.083)\end{array}$ \\
\hline Regulation border, $t-1{ }^{*}$ Non-dynamic & & & & $\begin{array}{l}-0.129 * \\
(0.078)\end{array}$ \\
\hline Dynamic $=$ Non-dynamic (F-test) & & & 3.84 ** & \\
\hline Observations & 217797 & 182104 & 217797 & 182104 \\
\hline$R$ square & 0.10 & 0.11 & 0.23 & 0.25 \\
\hline Country-year fixed effects & Yes & Yes & Yes & Yes \\
\hline Industry fixed effects & Yes & Yes & Yes & Yes \\
\hline
\end{tabular}

TFP is measured as a superlative index, calculated as described in equations 2 and 3 in the main text. Standard Errors are in parentheses. *, ${ }^{* *},{ }^{* * *}$ indicate statistical significance at the 10,5 and $1 \%$ levels, respectively. Agriculture, forestry, fishing, mining and construction are excluded, as are public administration, education and health sectors.

1. Dynamic firms are defined as firms that catch-up to the global frontier in their respective sector.

\section{Robustness Checks}

In order to evaluate the robustness of our findings, we check whether they are robust to an alternative definition of productivity and to the inclusion of additional variables that may affect the firm productivity. Table 2 replicates columns (1) and (3) of Table 1, using TFP estimates obtained via the semi-parametric method suggested by Levinsohn and Petrin (2003). These estimates are based on an estimation of country- and sector-specific production function coefficients, with TFP being the residual of the production function. The method uses material inputs in order to proxy for unobserved productivity shocks, which could create biased input coefficients in ordinary least square estimates. One drawback of the method is that because the TFP estimates come from country- and sector-specific parameterisations of 
the production function, one cannot draw comparisons across countries, which implied that we had to define the productivity frontier as the average productivity of the top 5\% of firms within the same sector and country, while the TFP index results are based on a global productivity frontier. This may be the reason why the estimated coefficient for the TFP gap between a firm and the technological frontier is one of the coefficients that differ most between Tables 1 and 2.

Our main findings, however, are quite similar using this different productivity definition. The coefficient for regulation remains significant, although now only at the $10 \%$ level, in our baseline specification. When we distinguish between the regulation effect on dynamic and non-dynamic firms, it loses its statistical significance for the non-dynamic firms, and stays highly significant for the dynamic firms. Note that even though both coefficients are statistically significant in Table 1, the estimated effect for dynamic firms is larger using the TFP index definition as well. This may suggest that regulation hampers particularly those firms that are on an upward trajectory of catching up with the best firms in the industry.

Table 2. Using Levinsohn-Petrin TFP estimates and country-specific frontier

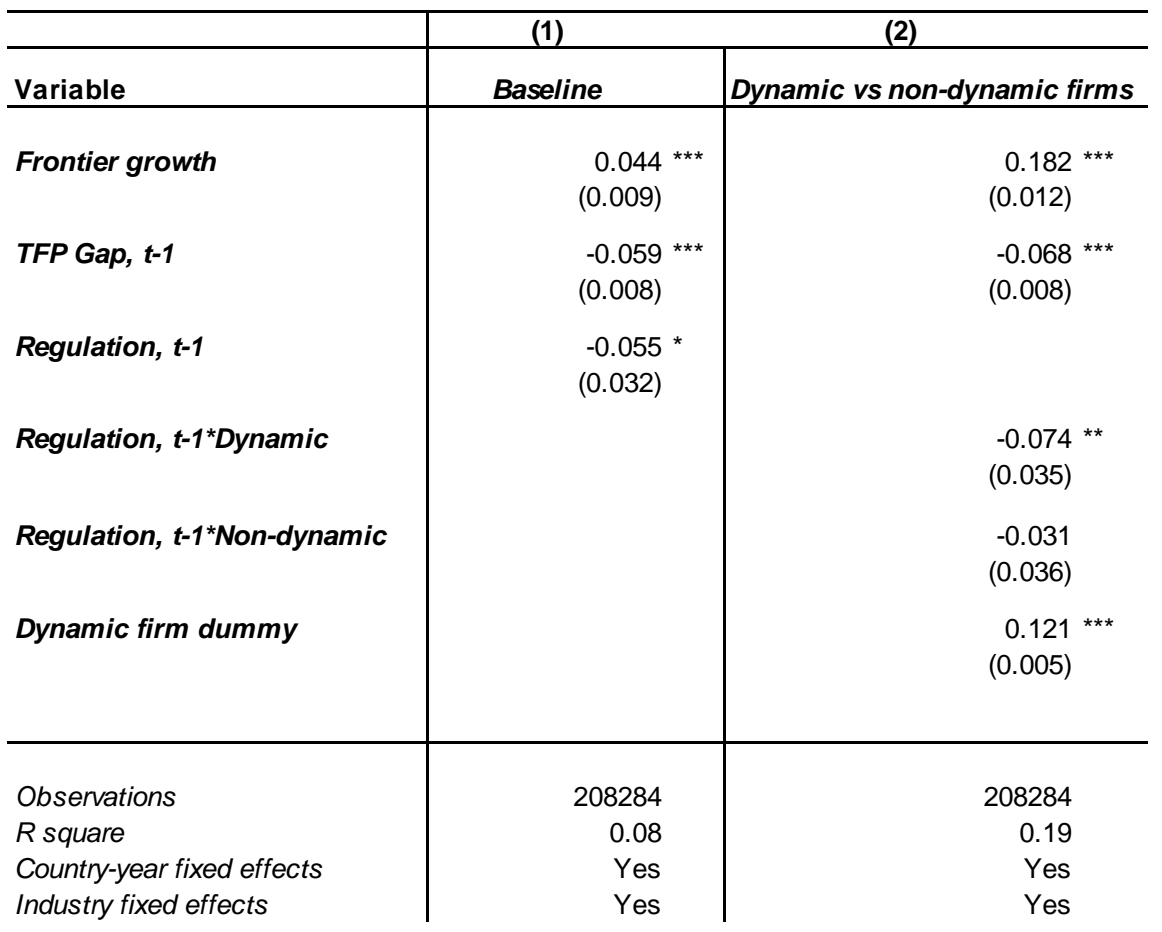

TFP is measured as a superlative index, calculated as described in equations 2 and 3 in the main text. Standard Errors are in parentheses. ${ }^{*},{ }^{* *},{ }^{* * *}$ indicate statistical significance at the 10,5 and $1 \%$ levels, respectively. Agriculture, forestry, fishing, mining and construction are excluded, as are public administration, education and health sectors. Dynamic firms are defined as firms that catch-up to the national technology frontier in their respective sector.

As a second robustness check, we introduce measures of labour market regulations and of financial development into the regression, to check whether our estimated regulation effect may be due to crosscountry correlations between different policies. However, it should be stressed that our specifications presented in Table 2 always include country-specific year dummies that remove all country-wide changes in regulatory or institutional settings. This limits the degree to which most other policy changes could bias our findings on product market regulations even when they're not explicitly controlled for. 
We capture labour market regulation by exploiting an indicator of employment protection legislation (EPL) created by the OECD (OECD, 2010). This indicator measures the stringency of regulations affecting the hiring and firing of workers. EPL tends to raise labour adjustment costs possibly discouraging firms to innovate and adopt new technologies, both of which may require adjusting the workforce to reorganise the production process. The effect of stringent EPL on TFP is likely to be stronger in industries that are characterised by inherently large job turnover rates because of more frequent fluctuations in demand or wider technological shocks. For this reason, we interact the EPL indicator with a measure of job flows at the industry level from the United States in order to obtain a variable that varies at the country and sector level. ${ }^{10}$

In addition to considering labour market policies, we proxy for the degree of financial development by using the sum of two standard indicators of financial intermediation and the structure of financial systems: the ratio of bank credit to the private sector to GDP; and the share of stock market capitalisation in GDP. These indicators capture broad patterns of financial development and do not distinguish between sectors of the economy. To consider the possibility that financial development influences productivity outcomes differently depending on the extent to which firms in different sectors rely on external finance, we interact the synthetic indicator of financial development with a sector-specific measure of dependence on external finance (following Rajan and Zingales, 1998). The latter measure is constructed from the average ratio of debt to fixed assets across firms at the industry level (see Inklaar and Koetter, 2008, for a similar approach). In order to limit the possible endogeneity of this variable, we construct it only on the basis of firms from the United Kingdom, arguably the economy with the most developed financial market in our sample. Hence, the amount of external finance used by UK firms in different sectors is probably the best available proxy for the technologically-driven differences in exposure to external finance across sectors. ${ }^{11}$ Given that financial development is likely to have a positive effect (if any) on TFP, because it may improve firms' options for making productivity-enhancing investments regardless of current cashflow, the expected sign on this variable is positive.

Table 3 replicates our main regressions including these two additional policy measures. Our findings with respect to product market regulation are not affected by the inclusion of these additional controls. In both regressions, the coefficients of these additional explanatory variables are estimated with large standard errors and are not statistically significant at the conventional level. There are a number of possible explanations for this. Most importantly, our sample of mostly continental European countries (with the United Kingdom being the only exception to this) implies that there is not much variation in these policy variables. By extending our sample to other non-European countries, there might be enough variation to estimate a statistically significant effect. While it would be beyond the scope of this paper to explore these questions, we nonetheless take comfort from the fact that the product market regulation indicators remains statistically significant even once other policy dimensions are controlled for.

10

Flows in the United States are used as a benchmark because of data availability at a fine level of disaggregation and because the United States is one of the least regulated labour markets in the OECD and its job flows are likely to characterise well the technology and market-driven need for labour reallocation of different industries.

11 We have also tried a different sectoral measure of external dependence on finance, based on Compustat data for the US. This is a similar measure as the one originally employed by Rajan and Zingales (1998), except that it uses more recent data. Using this measure instead of the one employed below, we find the same results for product market regulation. It should be stressed, however, that the indicator used in Table 3 - the industry-level averages of the ratio of debt to fixed assets in the United Kingdom - drawing from the Amadeus database that also covers unlisted businesses is arguably more appropriate to characterise the average dependence of external finance than a measure based on Compustat for the United States that only considers larger listed businesses. 
Table 3. Controlling for additional policy variables

(using superlative index TFP and global frontier)

\begin{tabular}{|c|c|c|}
\hline Variable & Baseline model & Dynamic vs non-dynamic firms \\
\hline Frontier growth & $\begin{array}{l}0.066^{* * *} \\
(0.008)\end{array}$ & $\begin{array}{l}0.148 \text { *** } \\
(0.010)\end{array}$ \\
\hline TFP Gap, $t-1$ & $\begin{array}{l}-0.113^{* * *} \\
(0.009)\end{array}$ & $\begin{array}{l}-0.135^{* * *} \\
(0.010)\end{array}$ \\
\hline Regulation, $t-1$ & $\begin{array}{l}-0.090^{* * *} \\
(0.031)\end{array}$ & \\
\hline Regulation, $t-1^{\star}$ Dynamic & & $\begin{array}{l}-0.110^{* * *} \\
(0.034)\end{array}$ \\
\hline Regulation, $t-1^{\star}$ Non-dynamic & & $\begin{array}{l}-0.075^{* *} \\
(0.032)\end{array}$ \\
\hline Dynamic firm dummy & & $\begin{array}{l}0.1388^{* * *} \\
(0.005)\end{array}$ \\
\hline Labour Market Regulation & $\begin{array}{r}0.006 \\
(0.038)\end{array}$ & $\begin{array}{r}0.003 \\
(0.038)\end{array}$ \\
\hline Financial Development & $\begin{array}{r}0.006573 \\
(0.011)\end{array}$ & $\begin{array}{r}0.003249 \\
(0.012)\end{array}$ \\
\hline Dynamic = Non-dynamic (F-test) & & 3.25 * \\
\hline $\begin{array}{l}\text { Observations } \\
R \text { square } \\
\text { Country-year fixed effects } \\
\text { Industry fixed effects }\end{array}$ & $\begin{array}{r}209351 \\
0.08 \\
\text { Yes } \\
\text { Yes }\end{array}$ & $\begin{array}{r}209351 \\
0.22 \\
\text { Yes } \\
\text { Yes }\end{array}$ \\
\hline
\end{tabular}

Standard errors are in parentheses. ${ }^{*}{ }^{* *}$. ${ }^{* *}$ indicate statistical significance at the 10.5 and $1 \%$ levels, respectively. Agriculture, forestry, fishing, mining are excluded, as are public administration, education and health sectors. Dynamic firms are defined as firms that catchup to the global frontier in their respective sector. 


\section{Conclusion}

In this paper, we shed some light on the role of product market reforms for firm-level productivity patterns for a number of European countries. We use a large comparable panel data set of European firms, estimate firm-level productivity and relate it to detailed indicators of anti-competitive product market regulation. Our results confirm previous evidence from country studies that the level of competition may affect aggregate productivity and growth (see Aghion and Griffith, 2005 for a detailed theoretical and empirical analysis). In particular, our results suggest that product market regulations that curb competitive pressures tend to reduce the productivity performance of firms. Moreover, such regulation may have negative effects on allocative efficiency because they have a disproportionally strong effect on firms characterised by an above-average productivity growth. Domestic regulations that affect all regulated firms in the same way seem to be more important than border regulations in this context. 


\section{References}

Acemoglu, D., Aghion, P. and F. Zilibotti (2005). "Distance to Frontier, Selection and Economic Growth”, Journal of the European Economic Association. March 2006, v. 4, iss. 1, pp. 37-74

Aghion, P. and P. Howitt (1998). Endogenous Growth Theory, Cambridge: Mass.: The MIT Press.

Aghion, P. and R. Griffith (2005), Competition and Growth, Cambridge: Mass, The MIT Press.

Bertrand, M., E. Duflo and S. Mullainathan (2004), "How Much Should We Trust Differences in Differences Estimates", Quarterly Journal of Economics 119(1): 249-275.

Bourlès, R., G. Cette, J. Lopez, J. Mairesse and G. Nicoletti (2010), "Do product market regulations in upstream sectors curb productivity growth? Panel data evidence for OECD countries," NBER Working Paper 16520.

Caves, D., L. Christensen and E. Diewert (1982a), 'The Economic Theory of Index Numbers and the Measurement of Input, Output and Productivity”, Econometrica 50(6): 1393-1414.

Caves, D., L. Christensen and E. Diewert (1982b), "Multilateral Comparisons of Output, Input and Productivity Using Superlative Index Numbers”, Economic Journal 92: 73-86.

Conway, P and G. Nicoletti (2006), "Product Market Regulation in the Non-Manufacturing Sectors of OECD Countries: Measurement and Highlights," OECD Economics Department Working Papers 530, OECD, Economics Department.

Conway, P., de Rosa, D., Nicoletti, G., and F. Steiner. (2006). "Product Market Regulation and Productivity Convergence." OECD Economic Studies , No. 43: 39-76.

Griffith, R., S. Redding and H. Simpson (2009), "Technological Catch-Up And Geographic Proximity," Journal of Regional Science, vol. 49(4), pages 689-720.

Griffith, R., S. Redding and J. Van Reenen, 2004. "Mapping the Two Faces of R\&D: Productivity Growth in a Panel of OECD Industries," The Review of Economics and Statistics, MIT Press, vol. 86(4), pages 883-895, December.

Inklaar, R.,M.P. Timmer and B. van Ark (2008), "Market services productivity across Europe and the US," Economic Policy, CEPR, CES, MSH, vol. 23, pages 139-194, 01.

Inklaar, R. and M. Koetter (2008), "Financial Dependence and Industry Growth in Europe: BetterBanks and Higher Productivity", GGDC Research Memorandum GD-100, Groningen Growth and Development Centre, University of Groningen.

Levinsohn, J. and A. Petrin (2003). "Estimating Production Functions Using Inputs to Control for Unobservables," Review of Economic Studies pp. 317-342.

Moulton, B.R. (1991), "An Illustration of a Pitfall in Estimating the Effects of Aggregate Variables on Micro Units", Review of Economics and Statistics 72: 334-338.

OECD (2010). OECD Employment Outlook. Paris, France. 
Rajan, R. and L. Zingales (1998). "Financial Dependence and Growth", American Economic Review, June 1998 , v. 88 , iss. 3 , pp. 559-86

Woelfl, A., I. Wanner, T. Kozluk and G. Nicoletti (2009), “Ten years of product market reform in OECD countries - insights from a revised PMR indicator", OECD Economics Department Working Papers No. 695, OECD, Paris. 